\title{
A Self-assessment Checklist for Undergraduate Students' Argumentative Writing
}

\author{
Vahid Nimehchisalem (Corresponding author) \\ English Language Department, Faculty of Languages and Linguistics, University of Malaya \\ Email: nimechie@gmail.com \\ David Yoong Soon Chye \\ English Language Department, Faculty of Languages and Linguistics, University of Malaya \\ Sheena Kaur A/P Jaswant Singh \\ English Language Department, Faculty of Languages and Linguistics, University of Malaya \\ Siti Zaidah Zainuddin \\ English Language Department, Faculty of Languages and Linguistics, University of Malaya \\ Sara Norouzi \\ English Language Department, Faculty of Languages and Linguistics, University of Malaya \\ Sheren Khalid \\ English Language Department, Faculty of Languages and Linguistics, University of Malaya
}

Doi:10.7575/aiac.alls.v.5n.1p.65

URL: http://dx.doi.org/10.7575/aiac.alls.v.5n.1p.65
Received: 01/01/2014

Accepted: 28/02/2014

\begin{abstract}
With a growing emphasis on students' ability to assess their own written works in teaching English as a Second Language (ESL) writing courses, self-assessment checklists are today regarded as useful tools. These checklists can help learners diagnose their own weaknesses and improve their writing performance. This necessitates development of checklists that guide the learners in assessing their own writing. In this study, a self-assessment checklist was developed for undergraduate students in an ESL context to help them with their argumentative essays. This paper presents the related literature and theories, based on which the checklist was developed. The checklist is described and its potential theoretical and practical implications in ESL writing classes are discussed. Further research is necessary to refine the checklist through focus group studies with lecturers and students.
\end{abstract}

Keywords: English as a second language writing, self-assessment, checklists, argumentative writing

\section{Introduction}

Despite their importance, few self-assessment checklists are available to help university undergraduate students specifically in writing argumentative essays. The existing self-assessment checklists designed for ESL argumentative writing do not seem to be able to help these students improve their argumentative writing skills. One of the few selfassessment checklists tested for their effectiveness is presented by Honsa (2013). The checklist was generic and was accompanied by a guidance sheet. Although Honsa (2013) reports that the checklist helped the participants in the experimental group gain higher scores, she fails to mention the statistical significance of this difference. Moreover, nothing is mentioned on the validation procedure of this checklist which is also the case for most of the checklists available in the literature. Most of these checklists are generic and thus are not sensitive to the features that are specific to argumentative writing. Additionally, most checklists have not been developed on sound theoretical frameworks which can undermine their construct validity. For example, as it is the case with Honsa's (2013) checklist, it was adapted from a textbook by Oshima and Hogue (1997), who do not provide any theoretical framework based on which they selected its sub-constructs.

It has been discovered that learners' awareness of specific schematic structures helps them improve in their writing (Beck \& Jeffry, 2007). This way, they become familiar with the different parts of a piece of writing, the way these parts are meaningfully interrelated, and the way they can be organized to fulfill a certain purpose. Research has revealed a change in the genre of writing will lead to variations in schematic structure (Lock \& Lockhart, 1999). As a result several genre-specific rating scales (e.g., Connor \& Lauer, 1988; Glasswell et al., 2001; Wong, 1989) have been developed. However, to reiterate the aforementioned point, what is lacking in the literature is genre-specific selfassessment checklists, which help students evaluate and improve their own writing. 
This study explores a number of preliminaries in developing a self-assessment checklist prototype for undergraduate ESL students in order to aid them in assessing their own argumentative essays. It highlights some important variables that characterize effective self-assessment checklists, based on theories of language competence, language assessment, and argumentation.

\section{Self-Assessment Writing Checklists}

There are several writing self-assessment checklists discussed in this section. In the self-assessment checklist developed by the Council of Europe (2001), writing ability is classified into a 6-level scale of beginner (A1), elementary (A2), intermediate (B1), upper-intermediate (B2), advanced (C1), and proficiency $(\mathrm{C} 2)$ with a list of descriptors for each level. For example based on this checklist, a competent learner who has mastery over language at the last level (C2) can write clearly and effectively about everything ranging from letters and reports to articles, reviews, and summaries.

There are also self-assessment checklists which have been developed based on the available rating scales. Some researchers have used Jacobs et al.'s (1981) ESL Composition Profile to develop their own self-assessment checklists. The rubrics of this rating scale have been used by White and McGovern (1994) as well as Al-Hazmi and Scholfield (2007) to develop checklists which focus on different writing domains related to both form (grammar, vocabulary, mechanics, and text structure) and meaning (purpose, content, cohesion and response to readers, and main idea). These researchers used the ESL Composition Profile rubrics to provide explicit descriptions of these writing features to enable the learners in their studies to assess their own writing. With regard to content, learners were encouraged to evaluate their writings by asking questions on the relevance and adequacy of information, sufficient examples or evidence for supporting the main ideas, the existence of any gap in the information, and the balance in the amount of information provided for each section.

Scholars have emphasized the importance of assessing writing based on genre-specific instruments (Matsuda, 2003, Strong, 1999; Beck \& Jeffry, 2007; Jones, 1996; Hyland, 2003). Such instruments focus on specific genres and are sensitive to variations in the content and organizational structure of different modes of writing. For example, in a checklist developed by Paulus (1999) based on Faigley and Witte's (1981) taxonomy of revisions, the learners are encouraged to assess their writings based on domains such as development of ideas, word choice, effective reasoning, introduction, and conclusion.

Scholars like Flower et al. (1986) have emphasized the processes that take place in the minds of the students while using writing checklists. They believe that learners should be encouraged to revise and explain rather than merely evaluating their written works. Accordingly, Demirel and Enginarlar (2007) as well as Paulus (1999) developed selfassessment checklists prompting students to read what they have written, provide a list of the ideas discussed in each paragraph, evaluate the essay unity, and finally explain the possible ways to revise and improve their papers. It is claimed that these checklists can help students become actively involved in the process of analyzing and evaluating the quality of their writing (Demirel \& Enginarlar, 2007). However, one problem with such checklists is that they are limited only to the revision phase of writing. A comprehensive checklist should include all the stages of writing such as generating and organizing ideas and planning arguments besides revising or editing the written work.

One may also common come across with self-assessment checklists which have been developed by faculty members to help students assess their writing. The University of Technology Sydney's Faculty of Law (2013) for instance provides a written guide for law students. The checklist includes style (using plain English), drafting (putting ideas in logical order), coherent and cohesion markers, word choice, grammatical definitions, punctuation, as well as reference to statements of law and numbering. However, this checklist has a number of limitations. It lacks a theoretical background, is lengthy, is accompanied by a list of definitions for grammatical terms (and some guidelines that do not go beyond the basic writing skills), and does not specifically focus on argumentative writing skills. As another example, the UCLA School of Law's (n.d.) writing checklist provides a short list of dos and don'ts, such as word use, paragraphing, style, and grammatical accuracy. However, this checklist cannot be regarded as a self-standing guide for helping students with their argumentative writing since it only partially presents some of the features of a good argumentative essay. The checklist lacks comprehensiveness which is due to the fact that it was not developed based on a theoretical framework and which undermines its construct validity.

The next section provides a discussion of a theoretical framework that formulates the development of a genre-specific self-assessment checklist.

\section{Theoretical Framework}

The theoretical framework of this study is based on the Pyramid of Argumentation (Nimehchisalem, 2010) and the Process Approach, which are described in the following sub-sections.

\subsection{Pyramid of Argumentation}

The Pyramid of Argumentation adapts and integrates the elements of communicative language competence and argumentation. The Theory of Communicative Language Ability (Bachman, 1990), Taxonomy of Components of Language Competence (Bachman, 1990), the Theory of Classical Rhetoric (Kinneavy, 1971), and Model of Argument (Toulmin, 2003) are slightly modified and combined in the form of a pyramid to be discussed in the following sections. 


\subsubsection{Theory of Communicative Language Ability (Bachman, 1990)}

The Communicative Language Ability (CLA) includes the 'world knowledge' 'language competence', 'strategic competence', 'psychophysiological mechanisms' (discarded in the Pyramid of Argumentation), and 'context of situation' (Figure 1).

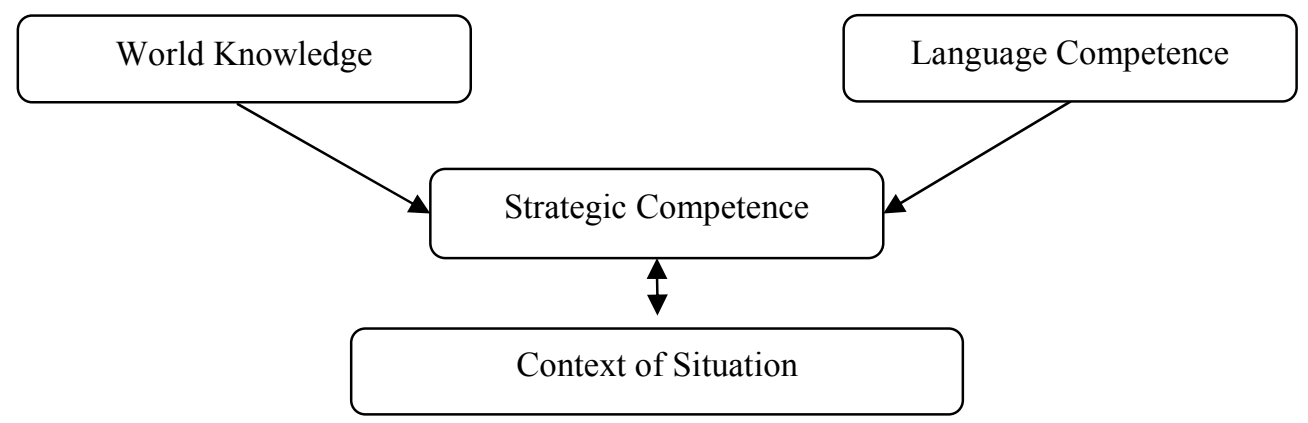

Figure 1. Components of Communicative Language Ability (Adapted from Bachman, 1990)

Based on Bachman's CLA theory, besides students' language competence their world or topical knowledge is also considered in assessing their writing. Equally important in writing assessment is strategic competence. According to Bachman and Palmer (1996, pp. 71-75) goal setting, planning, and assessment comprise the three areas of metacognitive strategy use where strategic competence can work. Strategic competence can help student writers 'set goals' based on what they intend to do with the language. They also use strategic competence to 'assess' their available topical and language knowledge resources in order to predict whether they can fulfill the task. Based on this assessment, they identify the most suitable resource that can help them complete the task. Additionally, 'planning' assists writers to decide on how to select the appropriate concepts from their existing language and world resources. Planning may involve outlining one's response to the task.

The final element of the CLA theory is the context of situation. In order to create an appropriate and effective argument, students should integrate their world and language knowledge in accordance with the context in which that communication takes place. Attention to the context will help them use a suitable style.

\subsubsection{Taxonomy of Components of Language Competence (Bachman, 1990)}

The Taxonomy of Language Competence Components is composed of 'organizational' and 'pragmatic' competencies (Bachman, 1990). While organizational competence deals with the way in which sentences and text are organized, pragmatic competence helps language users relate sentences and texts "to the communicative goals of the language user and to the features of language use setting" (Bachman \& Palmer, 1996, p. 68). Figure 2 presents an adapted version of the taxonomy.

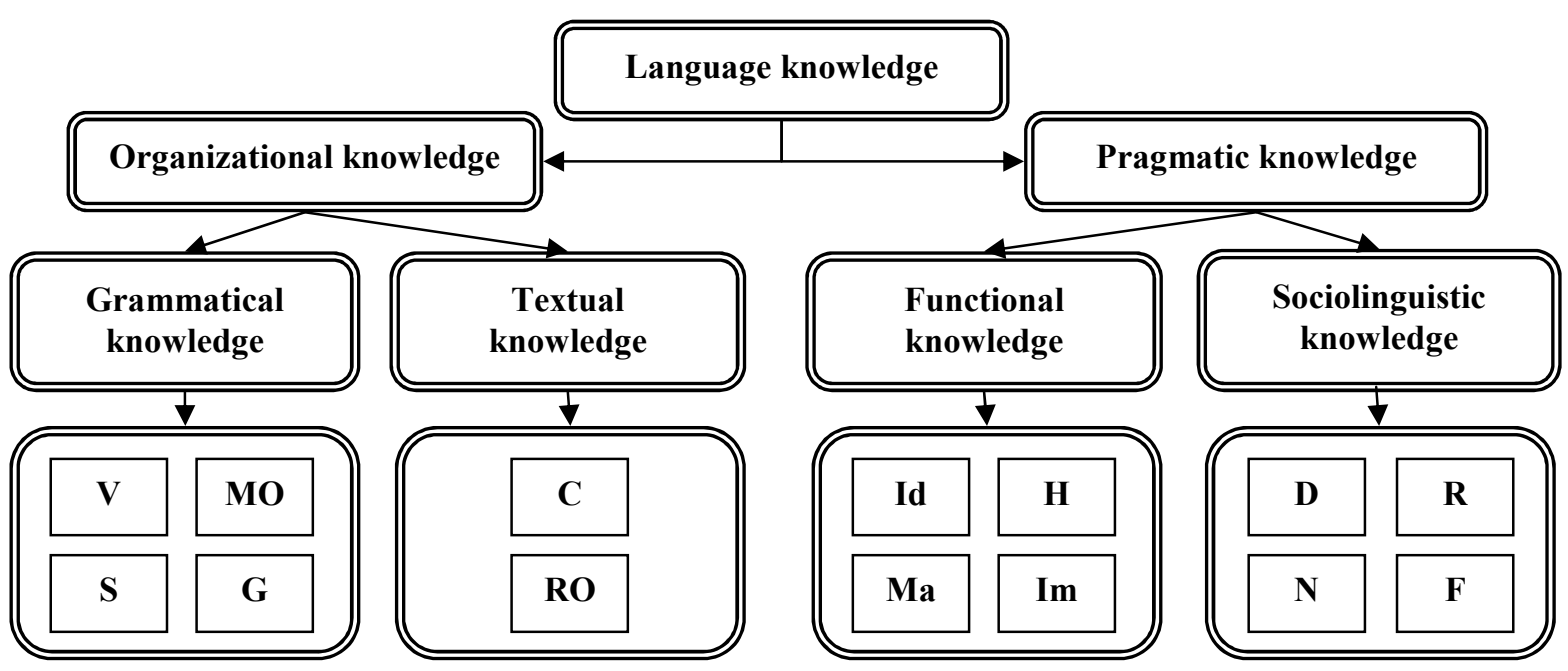

Figure 2. Components of Language Competence (Adapted from Bachman, 1990)

Key)

V: vocabulary

$\mathrm{C}$ : Cohesion

H: Heuristic

R: Register
S: Syntax

RO: Rhetorical Organization

Im: Imaginative

F: Figures of speech

\author{
Mo: Morphology \\ Id: Ideational \\ D: Dialect
}

\author{
G: Graphology \\ Ma: Manipulative \\ $\mathrm{N}$ : Naturalness
}


The two components of organizational knowledge are grammatical and textual knowledge that help students form and understand sentences. Grammatical knowledge is classified into vocabulary, syntax, morphology, and graphology. Textual knowledge, on the other hand, helps students form and understand texts that are longer than two sentences. The two components of textual knowledge are cohesion (explicit relationships among sentences), and rhetorical organization (organizational structure of written texts).

The two components of pragmatic knowledge include functional and sociolinguistic knowledge. Functional knowledge enables students to interpret the intended meanings. It allows them to i) share ideas and feelings (ideational function), ii) affect the world around (manipulative function), iii) learn and extend their knowledge (heuristic function), and iv) use language imaginatively for creative and aesthetic purposes (imaginative function). Finally, sociolinguistic knowledge enables students to make appropriate use of language regarding the social context. Dialects, registers, idioms, cultural references, as well as figures of speech can be encoded or decoded with the help of this knowledge.

\subsubsection{Theory of Classical Rhetoric (Kinneavy, 1971)}

Kinneavy (1971) reintroduced argumentation following Greek philosophers like Aristotle. The Theory of Classical Rhetoric includes ethos (ethical appeal), logos (logical appeal, replaced by Toulmin's Model of Argument in the Pyramid of Argumentation), pathos (emotional appeals, discarded in the Pyramid of Argumentation), rhetorical situation, rhetorical style, as well as arrangement (Kinneavy, 1971). The theory is slightly modified and presented in this section (Figure 3).

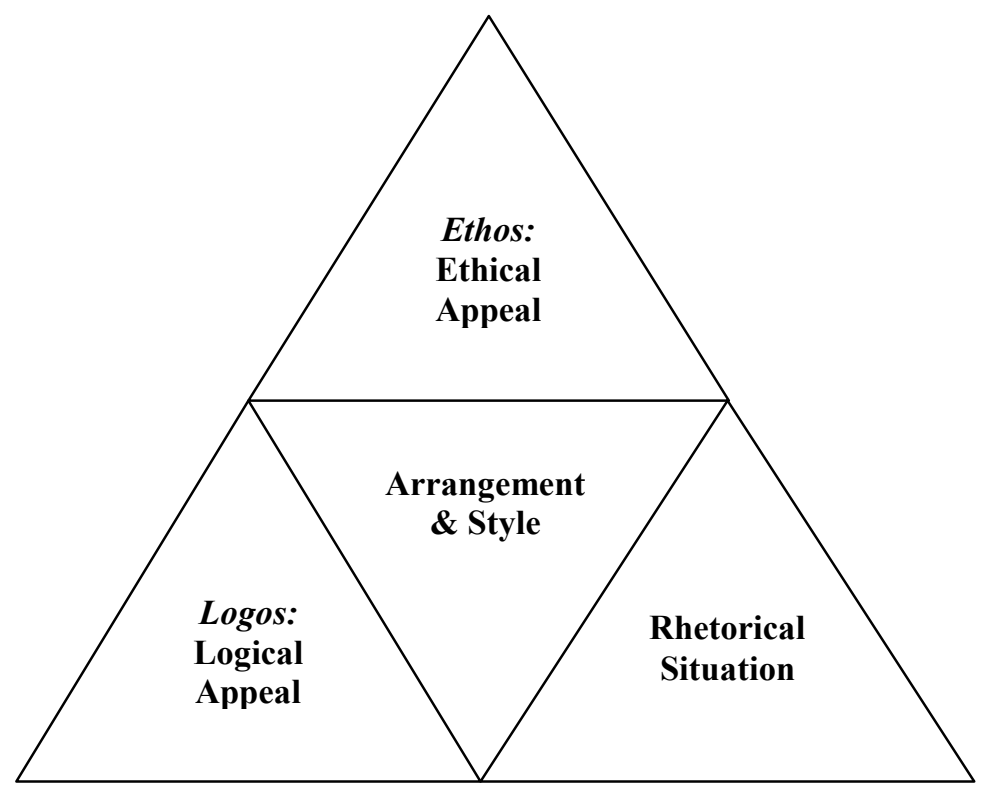

Figure 3. The Classical Rhetoric with slight modifications (adapted from Kinneavy, 1971)

Ethical appeal, also known as ethos or appeal to character helps writers create a good impression in their readers through good sense (by demonstrating astuteness and resourcefulness), good morals (by showing integrity), and good will (by showing good intentions).

According to Crowley and Hawhee (2004), rhetorical situation (kairos) is "the context of a rhetorical act; minimally made up of a rhetor, an issue, and an audience" (p. 437). The major elements of a rhetorical situation include occasion, purpose, and audience (Reid, 1993). A piece of language that sounds suitable for a particular rhetorical situation can be completely inappropriate for another.

Arrangement was commonly regarded to have six elements, including "exordium, narration, division, proof, refutation and peroration" (Lanham, 1991, p. 171). Exordium is the introduction, which is a general statement related to the topic and attracts readers' attention. Narration, or the thesis statement, is where one states one's position in relation to the topic. Division consists of a brief list of the ideas that one plans to mention in one's arguments. Proof, or confirmation, comes in the body paragraphs providing support for one's position. Refutation involves anticipating and acknowledging the possible objections and refuting them by providing reasons. Peroration, commonly referred to as conclusion, is the recap of the mentioned arguments.

The style of an argument can be determined by its topic, vocabulary, intended effect on the reader, and syntax (Lanham, 1991). The more serious a topic is, the more formal the style should be. Following ancient rhetoricians, Crowley (1994) presents correctness, clarity, appropriateness, and ornament as the four features of style. Using language which is consistent with the conventional grammar as well as conventions of spelling and punctuation is known as correctness. As one of the most crucial features of English language writing style, clarity means that the intended meaning is communicated transparently and lucidly. For Greek masters out-dated, technical, and new or 
colloquial words could diminish clarity, but this would depend on the rhetorical situation. When the reader is expected to have expert knowledge about the topic, technical words can contribute to clarity. Appropriateness necessitates the writer's sensitivity to the rhetorical situation (occasion, purpose, and audience). For example, a police report would require a more formal style than a personal letter. Finally, ornament is creative and impressive use of language by using figurative language like metaphors and similes, which if used appropriately, can make the argument more engaging.

In classical Greece, students were encouraged to make emotional appeals to contribute to the persuasive power of their arguments. In the related literature, argumentative and persuasive writing are often used interchangeably. However, there are researchers that differentiate the two. For instance, Glenn et al. (2004) state that making appeals to logic and ethics is typical in 'argumentative' writing whereas in 'persuasive' texts in addition to them frequent appeals are also made to emotions. Connor and Lauer (1988) make a similar distinction between the two. Additionally, Nimehchisalem (2010) reports that in his analysis of 100 argumentative essays, while there were 144 and 112 occurrences of logical and ethical appeals, emotional appeals had a negligibly low frequency (12), which was only $4 \%$ of the total number of appeals made in all the samples. For this reason, in the Pyramid of Argumentation, the emotional appeal was discarded.

Logical appeal can be achieved through rational thoughts and reasoning. It is divided into three elements of example, topic, and enthymeme (Kinneavy, 1971). In the Pyramid of Argumentation, these elements have been replaced by Toulmin's model due to its practicality and preciseness.

3.1.4 Model of Argument (Toulmin, 2003)

The Model of Argument consists of six interrelated elements of claim, data, warrant, qualifier, backing and rebuttal (Toulmin, 2003). In a good argument, the writer i) makes a claim, ii) provides data to support the claim, iii) may bridge the gap between the claim and data with a warrant, iv) supports the warrant by using backings, v) accounts for the probable objections with the help of rebuttals, and vi) may use qualifiers to indicate the level of certainty of these elements. Thus, the above-mentioned theories were integrated after they were slightly modified to form a three-sided pyramid on four columns (Figure 4).

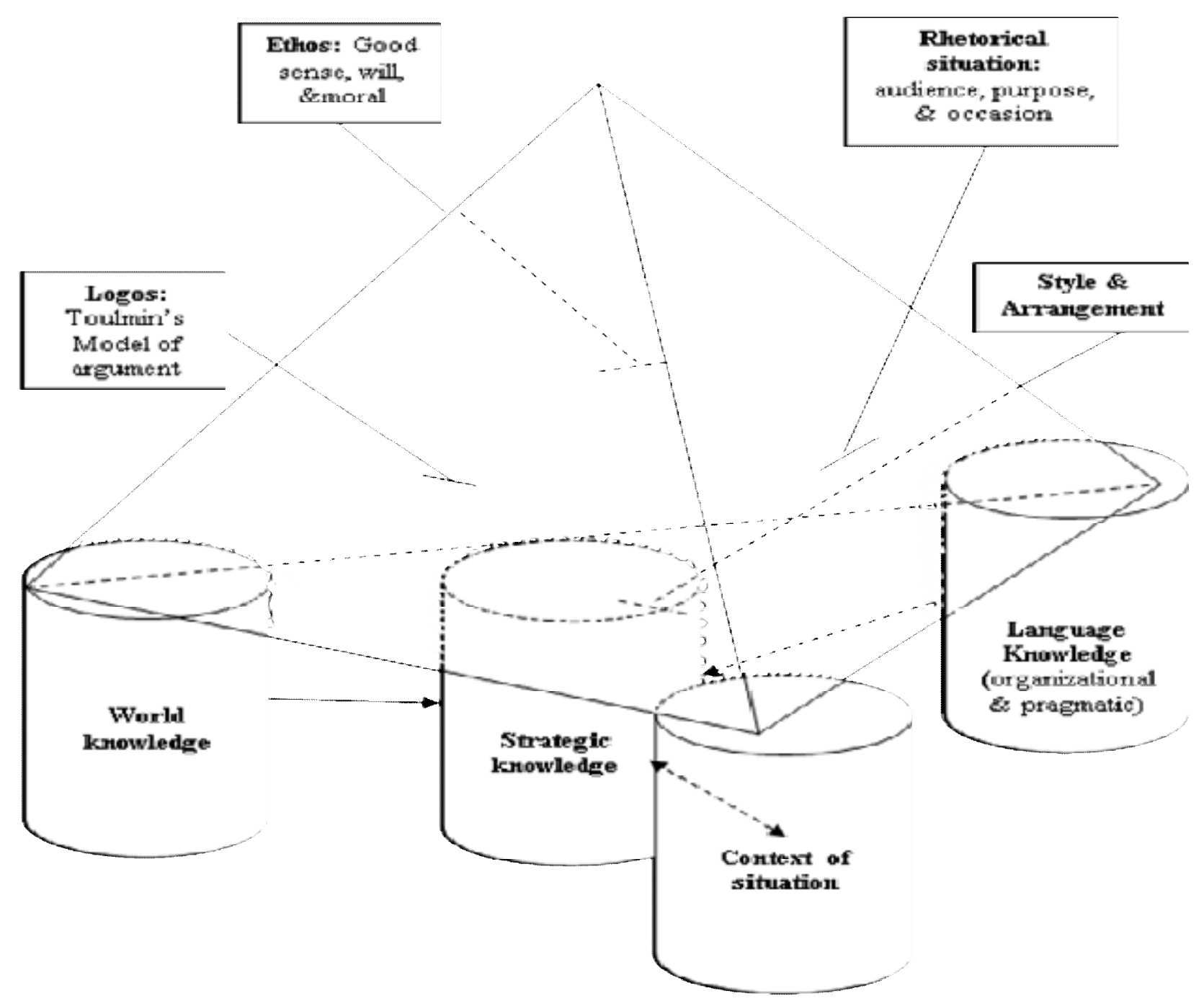

Figure 4. Pyramid of Argumentation 
As the figure illustrates, the Pyramid of Argumentation includes (i) ethical appeal, (ii) logical appeal represented by Toulmin's model, (iii) rhetorical situation, as well as (iv) style and arrangement. This integrative framework is also informed by both language and language assessment theories, represented by the four columns: (i) knowledge of language, (ii) strategic competence, (iii) context of situation, and (iv) world knowledge on which the pyramid lies.

\subsection{The Process Approach}

While the items of the checklist were based on the components of Pyramid of Argumentation, its overall structure was designed following the Process Approach. The Process Approach to ESL writing instruction focuses on the recursive processes occurring in the student writer's mind while drafting, revising, and editing rather than focusing on the final product (Elbow, 1973; Emig, 1971; Raimes, 1983). The proponents of the Process Approach argue that in their process of self-discovery, second language learners require a teacher's facilitative role in a positive and co-operative environment (Atkinson, 2003; Matsuda, 2003). Similarly, in the area of assessment, there is an increasing emphasis on continuous assessment of learners' involvement, effort, and progress. There is an increasing interest in formative assessment which promotes continuous focus on students' written drafts throughout their writing process (Alderson, 2004). In a classroom that follows this approach, the teacher helps learners discover and reformulate ideas in prewriting, writing and post-writing, by encouraging the students to express themselves freely (Flower \& Hayes, 1984; Raimes, 1991). In so doing, the teacher can gradually reduce their role and can motivate learners to write as much as possible (Hyland, 2003; Matsuda, 2003).

\section{The Self-Assessment Checklist for ESL Argumentative Writing}

Research indicates that among three types of teacher commentary, imperative comments result in more revisions in student drafts (Sugita, 2006). For this reason, the imperative mode was used to word the items of the prototype checklist (the full checklist is shown in Appendix A). The checklist is divided into three main sections, namely Before Writing (with 7 items), While Writing (with 4 items), and After Writing (with 9 items). Next to each item, students are given three choices: they may check the item 'done', 'pending' or 'not applicable'. As the task may not sometimes allow students to follow some of the items in the checklist, the choice 'not applicable' makes it more flexible by letting them disregard any of the items that they may find irrelevant. The checklist is followed by an extended guide, which gives further details for each item (Appendix B). The extended guide provides the rationale behind each item. Additionally, it uses examples to explain how to follow each item.

The first section of the checklist, Before Writing, emphasizes the fact that good writing is the result of good reading. The section also encourages students to list up ideas and plan before they actually start writing. Students also learn that they should consider different aspects of the issue under discussion. Finally, they are also instructed to be selective with the arguments that they choose to discuss. The next section, While Writing, is a step-by-step guide helping students write an argumentative piece. A feature of this section is that it encourages the students to write more fluently by starting with the body paragraphs. Delaying writing the introduction until one has written the body paragraphs helps students to save time and avoid writers' block. The section also emphasizes the importance of originality of the students' written work and avoidance of plagiarism. Another crucial point that is mentioned in this section is the idea of being relevant to the main idea. Students are finally given instructions on how to organize their writing into separate paragraphs.

The final section, After Writing, is meant to help students analyze, evaluate, and improve their written products. Basically derived from the taxonomy of Components of Language Competence (Bachman, 1990), this section provides a comprehensive guide for students to revise and edit their works. The section focuses on important features of ESL argumentative writing, including task fulfillment, content, organization, vocabulary, style, grammar, and mechanics. A strong point of this section is that it prompts students to seek help from more proficient peers by getting them to peerreview their written works. This highlights the social nature of writing in which individuals write to communicate with a clearly defined picture of their audience in mind, as the potential members of the target discourse community to which they are writing.

It should be noted that dividing the checklist into the aforementioned sections by no means suggests that the writing process is linear. The Process Approach views writing as a recursive process which cannot be simply broken into clearcut pre-/post-writing stages. A closer look at the checklist shows how students who follow the checklist will have to move back and forth in their written pieces as well as in the checklist itself before they complete their work.

\section{Conclusion}

The present checklist provides some pointers for students who wish to be more proficient in argumentative writing. Argumentative writing skills are important for university students since they enable them to articulate and document their thoughts well especially at the workplace after they graduate. These skills include i) planning for writing through reading related texts for identifying and analyzing the main arguments and counter-arguments, ii) writing coherently and cohesively by starting with a claim and providing evidence for it, iii) organizing and linking the main ideas clearly in the body paragraphs, iv) summarizing the main arguments followed by a conclusion, and v) checking the final draft for organization, vocabulary use, style, and grammatical accuracy. Such an inventory of writing skill awareness and practice can provide a basis for further studies on the correlation between its items and writing success, the effectiveness of its application in improving the writing skill, and the development of similar checklists for other genres. 
Furthermore, the present checklist is developed based on a theoretical framework in which the Theory of Classical Rhetoric, Toulmin's Model of Argument and Bachman's model have been integrated. The checklist supports student writers throughout the process of writing. Unlike most of the available checklists, it avoids merely focusing on students' written products; rather, it guides students as they start writing argumentative texts from the scratch. Moreover, in addition to helping students analyze and evaluate their written works, it provides recommendations based on which these written works can be improved.

From a broader perspective, one of the major issues for institutes of higher education today worldwide is how employable their graduates are. Communicative and argumentative ability of a job applicant is among the most crucial skills examined by most prospective employers. In order to build a successful career, most university graduates need to be able to examine the ideas for or against a case, provide proof to stand or refute a given position, and convince others to believe in one's argument and act accordingly. The present checklist is expected to help university students develop this important skill.

\section{References}

Alderson, J. C. (2004), Diagnosing foreign language proficiency: A teaching/testing interface, In G. Poedjosoedarmo (ed.), Teaching and Assessing Language Proficiency (pp. 112-123). Singapore: SEAMEO Regional Language Centre.

Al-Hazmi, S. H. \& Scholfield, P. (2007). Enforced revision with checklist and peer feedback in EFL writing: The example of Saudi University students. Scientific Journal of King Faisal University (Humanities and Management Sciences), 8(2), 237-267.

Atkinson, D. (2003), L2 writing in the post-process era: Introduction, Journal of Second Language Writing, 12, 3-15.

Bachman, L. F. (1990). Fundamental considerations in language testing. Oxford: Oxford University Press.

Bachman, L. F. \& Palmer, A. S. (1996). Language testing in practice. Oxford, UK: Oxford University Press.

Beck, S. W. \& Jeffry, J. V. (2007). Genres of high-stakes writing assessments and the construct of writing competence. Assessing Writing, 12 (1), 60-79.

Connor, U. \& Lauer, J. (1988). Cross-cultural variation in persuasive student writing. In A.C. Purves (Ed.), Writing across languages and cultures: Issues in contrastive rhetoric (pp. 206-227). Newbury Park, CA: Sage.

Council of Europe (2001). Common European framework of reference for languages, learning, teaching, assessment: A guide for users. Trim, John (Ed.). Strasbourg: Council of Europe, Language Policy Division.

Demirel, E. \& Enginarlar, H. (2007). Please say anything but yes or no: Fruitful peer feedback in writing, Sabanc1 University, School of Languages International Conference on Foreign Language Education, Tuning in: learners of Language, Language of Learners, İstanbul, Turkey, May 24-26.

Elbow, P. (1973). Writing without teachers. London: Oxford University Press.

Emig, J. (1971). The composing processes of twelfth graders. Urbana, IL: National Council of Teachers of English.

Faculty of Law, University Technology Sydney. (2013) Guide to written communication www.law.uts.edu.au/assessment/WrittenComm.pdf

Faigley, L., \& Witte, S. (1981). Analyzing revision. College Composition and Communication, 32, 400-414.

Flower, L. \& Hayes, J. R. (1984). Images, plans, and prose: The representation of meaning in writing. Written Communication, 1(1), 120-160.

Flower, L., Hayes, J.R., Carey, L., Scvhriver, K., \& Stratman, J.(1986). Detection, diagnosis and the strategies of revision. College Composition and Communication, 37, 16-55.

Glasswell, K., Parr, J., \& Aikman, M. (2001). Development of the asTTle writing assessment rubrics for scoring extended writing tasks. Technical Report 6, Project asTTle, University of Auckland.

Honsa, J. S. (2013). Self-assessment in EFL writing: A study of EFL intermediate students at a Thai University. Voices in Asia Journal, 1, 34-57.

Hyland, K. (2003). Genre-based pedagogies: A social response to process.Journal of Second Language Writing,12 (1), $17-29$.

Jacobs, H., Zingraf, S., Wormuth, D., Hartfiel, V. F. \& Hughey, J. (1981). Testing ESL composition: A practical approach. MA: Newbury House Publishers.

Jones, A. M. (1996). Dialogue: Genre and pedagogical purposes. Journal of Second Language Writing, 4(2), 181-190.

Kinneavy, J. A. (1971). A Theory of discourse: The aims of discourse. Englewood Cliffs, NJ: Prentice Hall. 
Lock, G. \& Lockhart, C. (1999). Genres in an academic writing class. Hong Kong Journal of Applied Linguistics, 3(2), 47-64.

Matsuda, P. K. (2003). Process and post-process: A discursive history. Journal of Second Language Writing, 12(1), 6583.

Nimehchisalem, V. (2010). Developing an analytic scale for argumentative writing of students in a Malaysian public university. (Unpublished doctoral dissertation). Universiti Putra Malaysia, Serdang, Malaysia.

Oshima, A, \& Hogue, A (1997). Writing Academic English. New York: Pearson.

Paulus, T. (1999). The effect of peer and teacher feedback on student writing. Journal of Second Language Writing, 8 , 265-289.

Raimes, A. (1983), Techniques in Teaching Writing. Oxford: Oxford University Press.

Reid, M. J. (1993). Teaching ESL Writing, New Jersey: Regents/ Prentice Hall.

Strong, W. (1999). Coaching writing development: Syntax revisited, options explored. In C. Cooper and L. Odell, (Eds.), Evaluating writing: The role of teacher's knowledge about text, learning, and culture (pp. 72-92). Urbana, Illinois: National Council of Teachers of English (NCTE).

Sugita, Y. (2006). The impact of teachers' comment types on students' revision. ELT Journal 60, 34-40.

Toulmin, S. (2003). The uses of argument. Cambridge: Cambridge University Press.

Wong, H. (1989). The development of a qualitative writing scale. UKM: University Kebangsaan Malaysia.

UCLA School of Law Legal Research and Writing Guide (n.d.) Writing and Editing Checklist. Retrieved from http://libguides.law.ucla.edu/content.php?pid=43631\&sid=353826

White, R. \& McGovern, D. (1994). Writing: A student's book. English for Academic Study Series. Hemel Hempstead, Hertfordshire: Prentice Hall Europe. 


\section{Appendix A: Self-assessment Checklist for English as a Second Language Argumentative} Writing

Based on the theories of language learning and teaching, this checklist has been developed to help you in writing argumentative papers. The checklist items have been divided into three sections, before writing, while writing, and after writing. The checklist is followed by an extended guide, which provides more detailed descriptions and examples on some of the items that you may find hard to understand. In front of the items that you have followed or will consider, check the cell under 'Done' or 'Pending', respectively. You may decide to ignore some of the items depending on the task by checking the cell under 'Not applicable'.

\section{Before Writing}

\begin{tabular}{|c|c|c|c|}
\hline Item & Done & Pending & $\begin{array}{l}\text { Not } \\
\text { applicable }\end{array}$ \\
\hline 1. Review related texts. & & & \\
\hline 2. List a few arguments related to the topic. & & & \\
\hline 3. Keep only the strong arguments that you can write to support. & & & \\
\hline 4. List a few counter-arguments. & & & \\
\hline 5. Keep only the counter-arguments that you can refute. & & & \\
\hline $\begin{array}{l}\text { 6. Consider how different people from different backgrounds would } \\
\text { argue for or against this topic. }\end{array}$ & & & \\
\hline 7. Based on these items, plan the content of your paragraphs. & & & \\
\hline
\end{tabular}

\section{While Writing}

\begin{tabular}{|c|c|c|c|}
\hline Item & Done & Pending & $\begin{array}{l}\text { Not } \\
\text { applicable }\end{array}$ \\
\hline \multicolumn{4}{|l|}{$\begin{array}{l}\text { 1. Draft the body paragraphs first. You do not have to start with the } \\
\text { introduction. }\end{array}$} \\
\hline \multicolumn{4}{|l|}{ 2. Write following your plan. } \\
\hline \multicolumn{4}{|l|}{ 3. Avoid plagiarism. Acknowledging the source if you are quoting. } \\
\hline \multicolumn{4}{|l|}{ 4. Every idea should be related to the topic. } \\
\hline \multicolumn{4}{|l|}{ 5. Present the content effectively. } \\
\hline \multicolumn{4}{|l|}{ 5.1. Make a claim. } \\
\hline \multicolumn{4}{|l|}{ 5.2. Provide strong evidence to support every claim. } \\
\hline \multicolumn{4}{|l|}{$\begin{array}{l}\text { 5.3. Elaborate on the link between your claim and evidence if you } \\
\text { anticipate it may not be clear for your reader. }\end{array}$} \\
\hline \multicolumn{4}{|l|}{$\begin{array}{l}\text { 5.4. Back up the link between the claim and evidence if you } \\
\text { anticipate it may be questioned by the reader. }\end{array}$} \\
\hline \multicolumn{4}{|l|}{ 5.5. Anticipate rebuttals and provide proof for rejecting them. } \\
\hline \multicolumn{4}{|l|}{ 5.6. Use qualifiers (e.g., certainly) to show the strength of arguments. } \\
\hline \multicolumn{4}{|l|}{ 6. Organize your ideas. } \\
\hline \multicolumn{4}{|l|}{$\begin{array}{l}\text { 6.1. Present your arguments and counter-arguments in the body } \\
\text { paragraphs. }\end{array}$} \\
\hline \multicolumn{4}{|l|}{$\begin{array}{l}\text { 6.2. At the beginning of the first paragraph, write a general statement } \\
\text { about the topic. }\end{array}$} \\
\hline \multicolumn{4}{|l|}{$\begin{array}{l}\text { 6.3. In the first paragraph, clearly state your position in the argument. } \\
\text { Alternatively, you may state your purpose of writing this paper. }\end{array}$} \\
\hline \multicolumn{4}{|l|}{$\begin{array}{l}\text { 6.4. At the end of the first paragraph, you may briefly list the } \\
\text { arguments and counter-arguments to be discussed in the paper. }\end{array}$} \\
\hline \multicolumn{4}{|l|}{ 6.5. Present a summary of your arguments and conclude. } \\
\hline \multicolumn{4}{|l|}{ 6.6. Link your sentences together. } \\
\hline \multicolumn{4}{|l|}{ 6.7. Link your ideas together logically. } \\
\hline $\begin{array}{l}\text { 7. Revise the first draft of your paper to improve its content and } \\
\text { organization. }\end{array}$ & & & \\
\hline
\end{tabular}

\section{After Writing}

\begin{tabular}{|c|c|c|c|}
\hline Item & Done & Pending & $\begin{array}{l}\text { Not } \\
\text { applicable }\end{array}$ \\
\hline \multicolumn{4}{|l|}{ 1. Fulfill the task. } \\
\hline \multicolumn{4}{|l|}{ 1.1. Consider the word limit. } \\
\hline \multicolumn{4}{|l|}{ 1.2. Remove the irrelevant ideas. } \\
\hline \multicolumn{4}{|l|}{ 1.3. Respond to all parts of the task. } \\
\hline \multicolumn{4}{|l|}{ 2. Present the content effectively. } \\
\hline \multicolumn{4}{|l|}{ 3. Check the organization of your paper. } \\
\hline 4. Check your use of vocabulary. & & & \\
\hline
\end{tabular}


4.1. Using technical words is good but you should avoid using words that you do not know how to use.

4.2. Avoid repetition by using synonyms and antonyms.

4.3. Avoid incorrect forms.

4.4. Make sure the right words come together.

4.5. It is good to use idioms, but some readers do not like clichés.

5 . Check your style.

5.1. Keep your style formal.

5.2. Keep it clear.

5.3. Make it engaging.

6. Check your grammar.

6.1. Use verbs correctly.

6.2. Avoid fragments.

6.3. Use nouns correctly.

6.4. Use adjectives and adverbs correctly.

6.5 . Use articles correctly.

6.7. Use prepositions correctly.

6.8. Avoid faulty comparisons.

6.9. Take case of parallel structures.

6.10. Use complex structures correctly.

7. Focus on mechanics.

7.1. Check your spelling.

7.2. Capitalize words like names.

7.3. Use punctuation marks correctly.

8. Request a peer to review your final draft and give you feedback.

9. Proofread the paper considering items 1-7.

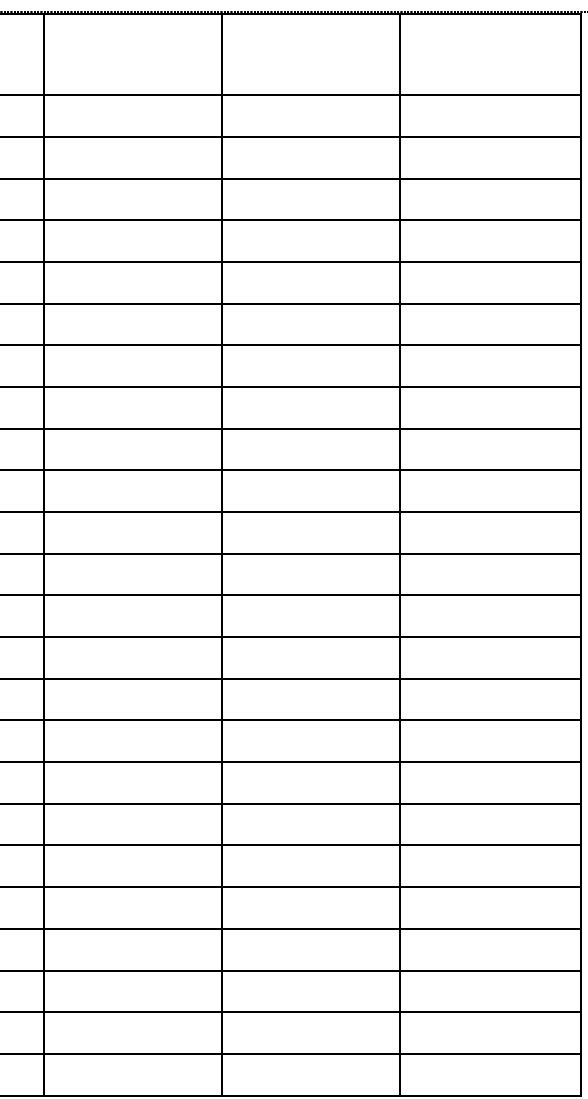


Appendix B: Extended Guide for Using Self-assessment Checklist for ESL Argumentative

\section{Writing}

This extended guide provides more detailed descriptions and examples on the items of the Self-assessment Checklist for ESL Argumentative Writing.

\section{Before Writing}

\begin{tabular}{|c|c|}
\hline Item & Why \& How? \\
\hline $\begin{array}{l}\text { 1. Review related } \\
\text { texts. }\end{array}$ & $\begin{array}{l}\text { Why? } \\
\text { - You may find ideas to be included in your paper. } \\
\text { - You may find interesting quotations. } \\
\text { - You may pick up a few useful words that you may use in your own paper. } \\
\text { How? } \\
\text { - Read books, magazine, or reliable internet sources. } \\
\text { - Listen to related material. }\end{array}$ \\
\hline $\begin{array}{l}\text { 2. List a few } \\
\text { arguments related } \\
\text { to the topic. }\end{array}$ & $\begin{array}{l}\text { Why? } \\
\text { - Planning your arguments helps you save time. } \\
\text { - Thinking about the topic before you start writing helps you write relevantly. } \\
\text { How? } \\
\text { - Use mind-maps in the form of cluster diagrams to list your ideas in a graphic way. } \\
\text { - Outline your ideas. }\end{array}$ \\
\hline $\begin{array}{l}\text { 3. Keep only the } \\
\text { strong arguments } \\
\text { that you can write } \\
\text { to support. }\end{array}$ & $\begin{array}{l}\text { Why? } \\
\text { - When you are not convinced that your argument is strong, neither will your reader. } \\
\text { - You support an argument in many ways, but be selective because of the time and } \\
\text { word limit. } \\
\text { How? } \\
\text { - Strong arguments are those in which the relationship between your claim and proof is } \\
\text { evident. } \\
\text { - Choose arguments for which you have enough evidence to support. }\end{array}$ \\
\hline $\begin{array}{l}\text { 4. List a few } \\
\text { counter- } \\
\text { arguments. }\end{array}$ & $\begin{array}{l}\text { Why? } \\
\text { - When you are willing to consider different aspects of the issue fairly, you r reader } \\
\text { trusts you more willingly. } \\
\text { - Your openness shows your good will which adds to your credibility. } \\
\text { - It shows you are a mature arguer and aware that reality is relative. } \\
\text { - As someone who is supporting an issue, if you raise some opposite arguments and } \\
\text { then provide proof to reject them, you inoculate those readers who are reluctant to } \\
\text { agree with you. } \\
\text { How? } \\
\text { - Think of what cons would say to oppose your argument. }\end{array}$ \\
\hline $\begin{array}{l}\text { 5. Keep only the } \\
\text { counter- } \\
\text { arguments that } \\
\text { you can refute. }\end{array}$ & $\begin{array}{l}\text { Why? } \\
\text { - If you draw attention to strong counter-arguments, you will have to spend too much } \\
\text { time and write too many words to provide support to reject them. This will reduce the } \\
\text { strength of the main argument. } \\
\text { How? } \\
\text { - Think of the ideas that you can present to reject each counter-argument. Keep the } \\
\text { ones for which you are able to think of some ideas. }\end{array}$ \\
\hline $\begin{array}{l}\text { 6. Consider how } \\
\text { different people } \\
\text { from different } \\
\text { backgrounds } \\
\text { would argue for } \\
\text { or against this } \\
\text { topic. }\end{array}$ & $\begin{array}{l}\text { Why? } \\
\text { - This will help you think differently and add to the creativity value of your writing. } \\
\text { - This will help you avoid writers' block. } \\
\text { How? } \\
\text { - Think of what different people from different geographical, cultural, and professional } \\
\text { backgrounds would say about the topic; e.g., individuals from developed or } \\
\text { developing countries may have varying views about it. }\end{array}$ \\
\hline $\begin{array}{l}\text { 7. Based on these } \\
\text { items, plan the } \\
\text { content of your } \\
\text { paragraphs. }\end{array}$ & $\begin{array}{l}\text { Why? } \\
\text { - Planning your writing helps you avoid having to remove irrelevant or weak } \\
\text { arguments after you have written them. } \\
\text { How? } \\
\text { - Outline the selected ideas or number the arguments to be included in your paper. }\end{array}$ \\
\hline
\end{tabular}

\section{While Writing}

\begin{tabular}{|l|l|}
\hline Item & Why \& How? \\
\hline 1. Draft the body & Why? \\
paragraphs first. & • Starting with the introduction may cause writer's block. \\
$\begin{array}{l}\text { You do not have } \\
\text { to start with the } \\
\text { introduction. }\end{array}$ & $\begin{array}{l}\text { Y You may waste time by writing ideas that you may have to remove later because you } \\
\text { do not include them in the paper. }\end{array}$ \\
\hline
\end{tabular}




\begin{tabular}{|c|c|}
\hline Item & Why \& How? \\
\hline & $\begin{array}{l}\text { - Based on your outline, write your body paragraphs first. } \\
\text { - Write your introduction based on what you have written in the body of the paper. }\end{array}$ \\
\hline $\begin{array}{l}\text { 2. Avoid plagiarism. } \\
\text { Acknowledging } \\
\text { the source if you } \\
\text { are quoting. }\end{array}$ & $\begin{array}{l}\text { Why? } \\
\text { - Attributing others' ideas or statements to yourself is considered unethical. } \\
\text { How? } \\
\text { - Use quotation marks and make references to the sources from which you accessed an } \\
\text { idea. }\end{array}$ \\
\hline $\begin{array}{l}\text { 3. Every idea should } \\
\text { be related to the } \\
\text { topic. }\end{array}$ & $\begin{array}{l}\text { Why? } \\
\text { - Relevance is the most important matter when it comes to argumentative writing. } \\
\text { - Irrelevant ideas will mean that you have written to fill the paper rather than fulfilling } \\
\text { the task. } \\
\text { How? } \\
\text { - Continuously ask yourself whether what you are writing can directly or indirectly be } \\
\text { linked to the topic. } \\
\text { - When you anticipate your reader may not be able to see the relevance, you may have } \\
\text { to explicitly show the relevance of some statements to the topic. }\end{array}$ \\
\hline $\begin{array}{l}\text { 4. Organize your } \\
\text { ideas. }\end{array}$ & $\begin{array}{l}\text { Why? } \\
\text { - When you write, you should be able to create order out of the anarchy of ideas that } \\
\text { you have listed down during brainstorming. } \\
\text { How? } \\
\text { - Your ideas and arguments should have a logical order. } \\
\text { - Each paragraph should present one idea at a time. } \\
\text { There should be a logical link between paragraphs. }\end{array}$ \\
\hline $\begin{array}{l}\text { 4.1. First, you } \\
\text { may make a } \\
\text { general statement } \\
\text { about the topic. }\end{array}$ & $\begin{array}{l}\text { Why? } \\
\text { - This will help you attract the reader's attention. } \\
\text { How? } \\
\text { - This general statement is called 'introduction' which usually comes at the beginning } \\
\text { of the first paragraph. }\end{array}$ \\
\hline $\begin{array}{l}\text { 4.2. Second, } \\
\text { clearly state your } \\
\text { position in the } \\
\text { argument. } \\
\text { Alternatively, } \\
\text { you may state } \\
\text { your purpose in } \\
\text { writing this } \\
\text { paper. }\end{array}$ & $\begin{array}{l}\text { Why? } \\
\text { - This will make it easy for your reader to follow your arguments throughout your } \\
\text { paper. } \\
\text { How? } \\
\text { - This is called 'thesis statement'. } \\
\text { - It comes in the first paragraph after the introduction. } \\
\text { - It shows what you really think about the topic. } \\
\text { - Some writers may delay explicitly stating their position, which is also acceptable. If } \\
\text { this is your choice, state your purpose instead. }\end{array}$ \\
\hline $\begin{array}{l}\text { Third, you } \\
\text { may briefly list } \\
\text { the arguments } \\
\text { and counter- } \\
\text { arguments to be } \\
\text { discussed in the } \\
\text { paper. }\end{array}$ & $\begin{array}{l}\text { Why? } \\
\text { - It outlines your arguments throughout the paper, making it reader-friendly. } \\
\text { How? } \\
\text { - This is called 'division', which comes in the first paragraph after the thesis statement. } \\
\text { - Write the division in a telegraphic manner as in a list. } \\
\text { - Make sure the items in the list are grammatically parallel; e.g., This paper discusses } \\
\text { three reasons for avoiding smoking, namely medical, social, and economic }\end{array}$ \\
\hline $\begin{array}{l}\text { 4.4. Present your } \\
\text { arguments and } \\
\text { counter- } \\
\text { arguments in the } \\
\text { next few } \\
\text { paragraphs. }\end{array}$ & $\begin{array}{l}\text { Why? } \\
\text { - Dividing your arguments into separate paragraphs helps your reader follow them } \\
\text { easily. } \\
\text { How? } \\
\text { - This is called 'proof', which constitutes the body paragraphs. } \\
\text { - Start drafting the argument that is the easiest for you. }\end{array}$ \\
\hline $\begin{array}{l}\text { 4.5. Present a } \\
\text { summary of your } \\
\text { arguments and } \\
\text { conclude. }\end{array}$ & $\begin{array}{l}\text { Why? } \\
\text { - Your conclusion signals to your reader that you are going to end the paper. } \\
\text { - This gives your reader a full synopsis of your ideas. } \\
\text { How? } \\
\text { - In the final paragraph, state the gist of the arguments discussed in the paper and then } \\
\text { conclude. }\end{array}$ \\
\hline $\begin{array}{l}\text { 4.6. Link your } \\
\text { sentences } \\
\text { together. }\end{array}$ & $\begin{array}{l}\text { Why? } \\
\text { - This helps you reader follow your ideas more easily. } \\
\text { How? } \\
\text { - This feature is called 'cohesion', which means the clauses and sentences are tied well } \\
\text { together. } \\
\text { - You may use connectors (e.g., however, therefore, etc.) to do this, but you do not } \\
\text { have to. }\end{array}$ \\
\hline
\end{tabular}




\begin{tabular}{|c|c|}
\hline Item & Why \& How? \\
\hline & - Use connectors correctly. \\
\hline $\begin{array}{l}\text { 4.7. Link your } \\
\text { ideas together } \\
\text { logically. }\end{array}$ & $\begin{array}{l}\text { Why? } \\
\text { - English is a language in which the writer is responsible for clearly communicating the } \\
\text { message with the reader. } \\
\text { - This is another way to clearly link the ideas in different paragraphs together and make } \\
\text { it easy for the reader to follow the arguments. } \\
\text { How? } \\
\text { - This is called 'coherence', which means the ideas and arguments should be logically } \\
\text { linked to one another. } \\
\text { - You may use transitional signals; e.g., In addition to the sociological reasons, } \\
\text { discussed in the previous section, there are also psychological reasons to avoid } \\
\text { smoking. }\end{array}$ \\
\hline
\end{tabular}

\begin{tabular}{|c|c|}
\hline Item & Why \& How? \\
\hline 1. Fulfill the task. & $\begin{array}{l}\text { Why? } \\
\text { - Even if you write very well but you fail to fulfill the task, your writing will be irrelevant. } \\
\text { How? } \\
\text { - Always ask yourself, "What does this task want from me?" }\end{array}$ \\
\hline $\begin{array}{l}\text { 1.1. Consider } \\
\text { the word } \\
\text { limit. }\end{array}$ & $\begin{array}{l}\text { Why? } \\
\text { - When you write below the word limit, your reader may assume you did not have enough } \\
\text { ideas to write about the task. } \\
\text { How? } \\
\text { - Count the number of the words in one line and multiply it by the total number of lines in } \\
\text { your paper. }\end{array}$ \\
\hline $\begin{array}{l}\text { 1.2. Remove the } \\
\text { irrelevant } \\
\text { ideas. }\end{array}$ & $\begin{array}{l}\text { Why? } \\
\text { - The ideas that are irrelevant to the task and topic will reduce the coherence of your } \\
\text { writing and therefore its effectiveness. } \\
\text { How? } \\
\text { - Remove the statements that are not related or cannot be indirectly linked to the topic. }\end{array}$ \\
\hline $\begin{array}{l}\text { 1.3. Respond to } \\
\text { all parts of the } \\
\text { task. }\end{array}$ & $\begin{array}{l}\text { Why? } \\
\text { - Some tasks have different parts. If you cover only one and neglect others, you will not } \\
\text { miss the scores assigned for those parts. } \\
\text { How? } \\
\text { - While you are reading the task, number its different parts and then distribute your time } \\
\text { and energy evenly to respond to each part. }\end{array}$ \\
\hline $\begin{array}{l}\text { 2. Present the } \\
\text { content } \\
\text { effectively. }\end{array}$ & $\begin{array}{l}\text { Why? } \\
\text { - It is always important to give yourself one more chance to review the content before you } \\
\text { submit a paper. } \\
\text { How? } \\
\text { - Review the content based on the items in section 'While Writing' } 4 \text {. } \\
\text { You can review your paper considering this and the next item (organization) together to } \\
\text { save time. }\end{array}$ \\
\hline $\begin{array}{l}\text { 3. Check the } \\
\text { organization } \\
\text { of your paper. }\end{array}$ & $\begin{array}{l}\text { Why? } \\
\text { - How you organize your arguments is sometimes as important as the arguments } \\
\text { themselves. } \\
\text { How? } \\
\text { - See section 'While Writing' } 5 \text {. }\end{array}$ \\
\hline $\begin{array}{l}\text { 4. Check your } \\
\text { use of } \\
\text { vocabulary. }\end{array}$ & $\begin{array}{l}\text { Why? } \\
\text { - Words are the building blocks of any language, so it is important to choose the correct } \\
\text { words in your writing. } \\
\text { How? } \\
\text { - Use a dictionary that: } \\
\text { 1. is recent; } \\
\text { 2. provides the second, third, and other meanings of words accurately; } \\
3 . \quad \text { labels 'technical' or 'formal' words; and } \\
\text { 4. gives examples that show how you can use the word in a sentence. } \\
\text { - You can use dictionaries available online like www.dictionary.reference.com }\end{array}$ \\
\hline $\begin{array}{l}\text { 4.1. Using } \\
\text { technical } \\
\text { words is good } \\
\text { but avoid } \\
\text { using words }\end{array}$ & $\begin{array}{l}\text { Why? } \\
\text { - Using technical words shows your reader that you have expertise knowledge in the area. } \\
\text { - However, when you fail to use technical words accurately, you introduce yourself only } \\
\text { as an individual with insufficient expertise knowledge. } \\
\text { How? }\end{array}$ \\
\hline
\end{tabular}




\begin{tabular}{|c|c|}
\hline Item & Why \& How? \\
\hline $\begin{array}{l}\text { that you do } \\
\text { not know how } \\
\text { to use. }\end{array}$ & $\begin{array}{l}\text { - See how experts in the area use the technical words in their sentences. } \\
\text { - Check with a reliable dictionary or reference before you finalize your draft. }\end{array}$ \\
\hline $\begin{array}{l}\text { 4.2. Avoid } \\
\text { repetition by } \\
\text { using } \\
\text { synonyms and } \\
\text { antonyms. }\end{array}$ & $\begin{array}{l}\text { Why? } \\
\text { - Sometimes it is OK to repeat ideas in other words to emphasize their importance, but } \\
\text { repeating the same words and/or expressions all over the paper will show your reader } \\
\text { that you have a limited vocabulary range. } \\
\text { - Repetition also reduces the ability of your paper to engage the reader. } \\
\text { How? } \\
\text { - Paraphrase the ideas that you choose to repeat. } \\
\text { - If you have to repeat a word, you may decide to write its synonym or antonym. You may } \\
\text { also use online sources like www.thesaurus.com. } \\
\text { - You may decide to change an expression into a sentence. }\end{array}$ \\
\hline $\begin{array}{l}\text { 4.3. Avoid } \\
\text { incorrect } \\
\text { forms. }\end{array}$ & $\begin{array}{l}\text { Why? } \\
\text { - Using correct forms of words shows your reader that you are a highly proficient user of } \\
\text { the language. } \\
\text { - Incorrect word forms will make your reader assume that you are not an accurate person } \\
\text { which will reduce persuasive power of your paper. } \\
\text { How? } \\
\text { - Check with a reliable dictionary. (e.g.; Her father is a cook NOT 'cooker'; Give } \\
\text { someone advice NOT 'advise'). } \\
\text { - You can Google for "advise or advice". Remember to use quotation marks, "'." This will } \\
\text { direct you to useful links like www.translegal.com/common-mistakes/advise-vs- } \\
\text { - Some commonly problematic words include make and do (e.g., make an effort, do one's } \\
\text { best); like, alike, and unlike (e.g., a like manner, to be alike, unlike conventional } \\
\text { methods); other, another, and others (e.g., another issue, other issues, disagreeing with } \\
\text { others). }\end{array}$ \\
\hline $\begin{array}{l}\text { 4.4. Make sure } \\
\text { the right } \\
\text { words come } \\
\text { together. }\end{array}$ & $\begin{array}{l}\text { Why? } \\
\text { - Just like some people, some words also do not sit together. } \\
\text { - Putting the wrong words together will blur or may change the meaning. } \\
\text { How? } \\
\text { - Check with a reliable dictionary. (e.g., make [not 'do'] a mistake). } \\
\text { - You can Google for "make or do a mistake". Remember to use quotation marks, "'. } \\
\text { This will direct you to useful pages like } \\
\quad \text { www.ecenglish.com/learnenglish/lessons/collocations-learn-correct-english }\end{array}$ \\
\hline $\begin{array}{l}\text { 4.5. Using idioms } \\
\text { is good, but } \\
\text { some readers } \\
\text { do not like } \\
\text { clichés. }\end{array}$ & $\begin{array}{l}\text { Why? } \\
\text { - Idioms (e.g., killing two birds with one stone) and proverbs (e.g., Two heads are better } \\
\text { than one) are powerful persuasive tools. } \\
\text { - Using idioms that are over-used (e.g., Haste makes waste) or are informal (e.g., You } \\
\text { shouldn't bite off more than you can chew; That's the way the cookie crumbles) may } \\
\text { negatively affect your style. } \\
\text { How? } \\
\text { - Make sure the idiom is appropriate for the context of your argument. } \\
\text { - Make sure the idiom is not labelled 'derogatory' or 'informal' in a reliable dictionary. }\end{array}$ \\
\hline $\begin{array}{l}\text { 5. Check your } \\
\text { style. }\end{array}$ & $\begin{array}{l}\text { Why? } \\
\text { - It is possible to write the same argument in a way that it bores the reader. A good style } \\
\text { helps you engage your reader. } \\
\text { - Using the right style also helps you give your own unique voice to your writing. } \\
\text { How? } \\
\text { - Your style should be consistent. For example, avoid mixing formal and informal styles } \\
\text { - Ynless you do it with a special purpose. } \\
\text { - Your style should be adequate to the context and reader. }\end{array}$ \\
\hline $\begin{array}{l}\text { 5.1. Keep your } \\
\text { style formal. }\end{array}$ & $\begin{array}{l}\text { Why? } \\
\text { - Formal style is the most appropriate style for arguments. } \\
\text { - It is better to be unbiased and not personal in arguments. } \\
\text { How? } \\
\text { - Contractions are used in colloquial discourse. Avoid contractions (e.g., isn't); rather, use } \\
\text { - Uull forms (e.g., is not). } \\
\text { - Using pronouns, like you and I, makes your writing informal and personal. } \\
\text { argue' rather than, 'You may argue'. }\end{array}$ \\
\hline
\end{tabular}




\begin{tabular}{|c|c|}
\hline Item & Why \& How? \\
\hline 5.2. Keep it clear. & $\begin{array}{l}\text { Why? } \\
\text { - English is a writer responsible language; that is, writers are responsible for making sure } \\
\text { that the reader understands their text. } \\
\text { How? } \\
\text { - As far as possible, make it simple for the reader to understand your argument. } \\
\text { - If you anticipate that your reader cannot link your ideas together, clarify the link between } \\
\text { them explicitly. } \\
\text { - Avoid sentences that are too long. } \\
\text { - Avoiding sentences with disorganized forms and thus confusing meanings). }\end{array}$ \\
\hline $\begin{array}{l}\text { 5.3. Make it } \\
\text { engaging. }\end{array}$ & $\begin{array}{l}\text { Why? } \\
\text { - The more engaging a text is, the more effective it will be since the reader will read it } \\
\text { more attentively. } \\
\text { How? } \\
\text { - Avoid redundancies. } \\
\text { - Relate your arguments to interesting examples, proverbs, anecdotes, or metaphors. } \\
\text { - Be terse: use fewer words to communicate more ideas. Less is more. }\end{array}$ \\
\hline $\begin{array}{l}\text { 6. Check your } \\
\text { grammar. }\end{array}$ & $\begin{array}{l}\text { Why? } \\
\text { - Correct use of grammar is one of the first things that readers of academic works consider. } \\
\text { How? } \\
\text { - You can use helpful online sources like www.grammarly.com. } \\
\text { - You can also check with OWL Purdue Online Writing Lab at } \\
\text { https://owl.english.purdue.edu/owl/ and more specifically at } \\
\text { https://owl.english.purdue.edu/owl/section/1/. } \\
\text { - Check with a recent grammar book like Swan, M. (2005). Practical English usage. } \\
\text { Oxford: Oxford University Press. }\end{array}$ \\
\hline $\begin{array}{l}\text { 6.1. Use verbs } \\
\text { correctly. }\end{array}$ & $\begin{array}{l}\text { - Focus on the tenses and ensure they are consistent with the time expressions used. (e.g., } \\
\text { Sociologists have debated the issue for centuries). } \\
\text { - Verbs should agree with their subjects (e.g., The } \underline{\text { number of TV addicts is increasing). }} \\
\text { - Use passive and active verbs correctly (e.g., The issue has been debated). }\end{array}$ \\
\hline $\begin{array}{l}\text { 6.2. Avoid } \\
\text { fragments. }\end{array}$ & - Each sentence must have a subject and a verb. \\
\hline $\begin{array}{l}\text { 6.3. Use nouns } \\
\text { correctly. }\end{array}$ & $\begin{array}{l}\text { - Use possessive nouns correctly (e.g., students'attention). } \\
\text { - Use plural/singular noun correctly (e.g., several psychologists). } \\
\text { - Use countable and uncountable nouns correctly (e.g., much time; many hours). } \\
\text { - Be careful with irregular plural nouns (e.g., man, men; crisis, crises; criterion, criteria; } \\
\text { phenomenon, phenomena). } \\
\text { - Distinguish the person from the thing (e.g., poet, poem; sculptor, sculpture; actor, } \\
\text { acting). } \\
\text { - Nouns must agree with their pronouns (e.g., Students know what they are doing). }\end{array}$ \\
\hline $\begin{array}{l}\text { 6.4. Use } \\
\text { adjectives and } \\
\text { adverbs } \\
\text { correctly. }\end{array}$ & $\begin{array}{l}\text { - Adjectives describe nouns (e.g., important issues). } \\
\text { - Adverbs describe verbs or adjectives (e.g., heatedly debated). } \\
\text { - Position adjectives and adverbs correctly (e.g., opposing views; selected carefully). } \\
\text { - Be careful with -ly adjectives (e.g., costly, friendly, daily, lonely, northerly). } \\
\text { - Use -ed and -ing adjectives correctly (e.g., interesting program; interested audience). } \\
\text { - Be careful with predicate adjectives (e.g., lone child; The child was alone). }\end{array}$ \\
\hline $\begin{array}{l}\text { 6.5. Use articles } \\
\text { correctly. }\end{array}$ & $\begin{array}{l}\text { - Singular nouns must come with articles (e.g., the issue, an issue). } \\
\text { - Use } a \text { or an correctly (e.g., a subject; an issue). } \\
\text { - Use the with specific ideas and } a \text { or an with general ideas (e.g., the first day of May, a } \\
\text { day; the Pacific Ocean; an ocean). }\end{array}$ \\
\hline $\begin{array}{l}\text { 6.7. Use } \\
\text { prepositions } \\
\text { correctly. }\end{array}$ & $\begin{array}{l}\text { - Use the correct proposition (e.g., failure resulting in a tragedy; consult with an attorney). } \\
\text { - You may have missed a proposition. Add missing propositions (e.g., deal with a } \\
\text { problem). }\end{array}$ \\
\hline $\begin{array}{l}\text { 6.8. Avoid faulty } \\
\text { comparisons. }\end{array}$ & $\begin{array}{l}\text { - Use the correct form of comparatives/superlatives (e.g., good, better, best; bad, worse, } \\
\text { worst; more/less, most/ least significant). } \\
\text { - Compare two equal things (e.g., Problems of the present century are more profound than } \\
\text { those of the twentieth century). } \\
\text { - Compare two parallel structures (e.g., Trying to solve the problem is more important than } \\
\text { finding a solution for it. } \\
\text { - Use superlatives for one of the many cases, which is outstanding (e.g., It is the most } \\
\text { significant issue of all times/in human history/that has been experienced in human } \\
\text { history). }\end{array}$ \\
\hline $\begin{array}{l}\text { 6.9. Take case of } \\
\text { parallel }\end{array}$ & $\begin{array}{l}\text { - Use parallel forms before and after and/but/or (e.g., One must be sincere in what one } \\
\text { says and what one does./ They did so not because they wished to but because they had }\end{array}$ \\
\hline
\end{tabular}




\begin{tabular}{|c|c|}
\hline Item & Why \& How? \\
\hline structures. & $\begin{array}{l}\text { to./ The problem had to be solved by communicating or by fighting). } \\
\text { - Use parallel forms with both... and/either...or/neither ... nor/not only...but also (e.g., both } \\
\text { a practical and a clever solution, either at the end or in the middle of the process). }\end{array}$ \\
\hline $\begin{array}{l}\text { 6.10. Use } \\
\text { complex } \\
\text { structures } \\
\text { correctly. }\end{array}$ & $\begin{array}{l}\text { - Pay special attention to adjective clauses (e.g. Travelling is a hobby that teaches great } \\
\text { lessons.) } \\
\text { - Take care of noun clauses used as subjects (e.g. What really hurts is his ignorance.) } \\
\text { - Focus on reduced sentences (e.g. Having entered the room, she turned on the light./The } \\
\text { lamp, one of Edison's best known inventions, changed the face of the world.) } \\
\text { - Use inverted sentences correctly (e.g. Little is known about mysteries of the outer space; } \\
\text { Were one interested, one could try it). }\end{array}$ \\
\hline $\begin{array}{l}\text { 7. Focus on } \\
\text { mechanics. }\end{array}$ & $\begin{array}{l}\text { Why? } \\
\text { - Correct use of mechanics in your writing will make it more formal and clear. } \\
\text { How? } \\
\text { - Make sure you spell-check. } \\
\text { - Some words need to be capitalized. } \\
\text { - Use punctuation marks correctly. }\end{array}$ \\
\hline $\begin{array}{l}\text { 7.1. Check your } \\
\text { spelling. }\end{array}$ & $\begin{array}{l}\text { - Use a good dictionary for checking the spelling of words you are unsure of. } \\
\text { - Make sure you use consistent use of British or American spelling. }\end{array}$ \\
\hline $\begin{array}{l}\text { 7.2. Capitalize } \\
\text { words like } \\
\text { names. }\end{array}$ & $\begin{array}{l}\text { - Proper nouns should be capitalized (e.g., Malaysia, the Indian Ocean). } \\
\text { - The initial letters of every word coming at the beginning of every sentence must be } \\
\text { capitalized (e.g., The issue if open to debate). }\end{array}$ \\
\hline $\begin{array}{l}\text { 7.3. Use } \\
\text { punctuation } \\
\text { marks } \\
\text { correctly. }\end{array}$ & $\begin{array}{l}\text { - Separate sentences using full-stops (e.g., The issue is multi-faceted). } \\
\text { - Use commas to signal appositives (e.g., Cancer, the most dreaded disease of all times, is } \\
\text { caused by it). } \\
\text { - Commas come before and, or, so, but, yet (e.g., The paper concludes thus, but further } \\
\text { study is required to shed light on all aspects of the issue). } \\
\text { - Commas are used when dependent clauses come at the beginning of a sentence (e.g., } \\
\text { Before one decides, one must think). } \\
\text { - Use a semicolon before and a comma after adverb transitions like finally, as a result, } \\
\text { therefore, however, in contrast, however (e.g., Creativity must be the essence of } \\
\text { education; therefore, teachers must seek to nurture creativity in their students). } \\
\text { - For more punctuation rules visit useful online sources like } \\
\text { www.grammarbook.com/english_rules.asp. }\end{array}$ \\
\hline $\begin{array}{l}\text { 8. Request a peer } \\
\text { to review } \\
\text { your final } \\
\text { draft and give } \\
\text { you feedback. }\end{array}$ & $\begin{array}{l}\text { Why? } \\
\text { - Usually instructors will be too busy to read your work thoroughly. } \\
\text { How? } \\
\text { - Find a partner who is more proficient in English than you. } \\
\text { - Follow your peer's comments carefully to revise your work. } \\
\text { - Note that you cannot expect your work completely error-free after the peer-review. }\end{array}$ \\
\hline $\begin{array}{l}\text { 9. Proofread the } \\
\text { paper } \\
\text { considering } \\
\text { items } 1-7 \text {. }\end{array}$ & $\begin{array}{l}\text { Why? } \\
\text { - It is always good to have one last look at your work before you submit. } \\
\text { - This will help you avoid typos. } \\
\text { How? } \\
\text { - Make sure your sentences are structured correctly. } \\
\text { - Your sentences must make sense. } \\
\text { - There must be a relationship between each sentence and the sentences preceding or } \\
\text { following it. } \\
\text { - Accurate language must be used all over the paper. }\end{array}$ \\
\hline
\end{tabular}

